\title{
OXFAM GB STATEMENT ON MODERN SLAVERY For the financial year 2017/18
}
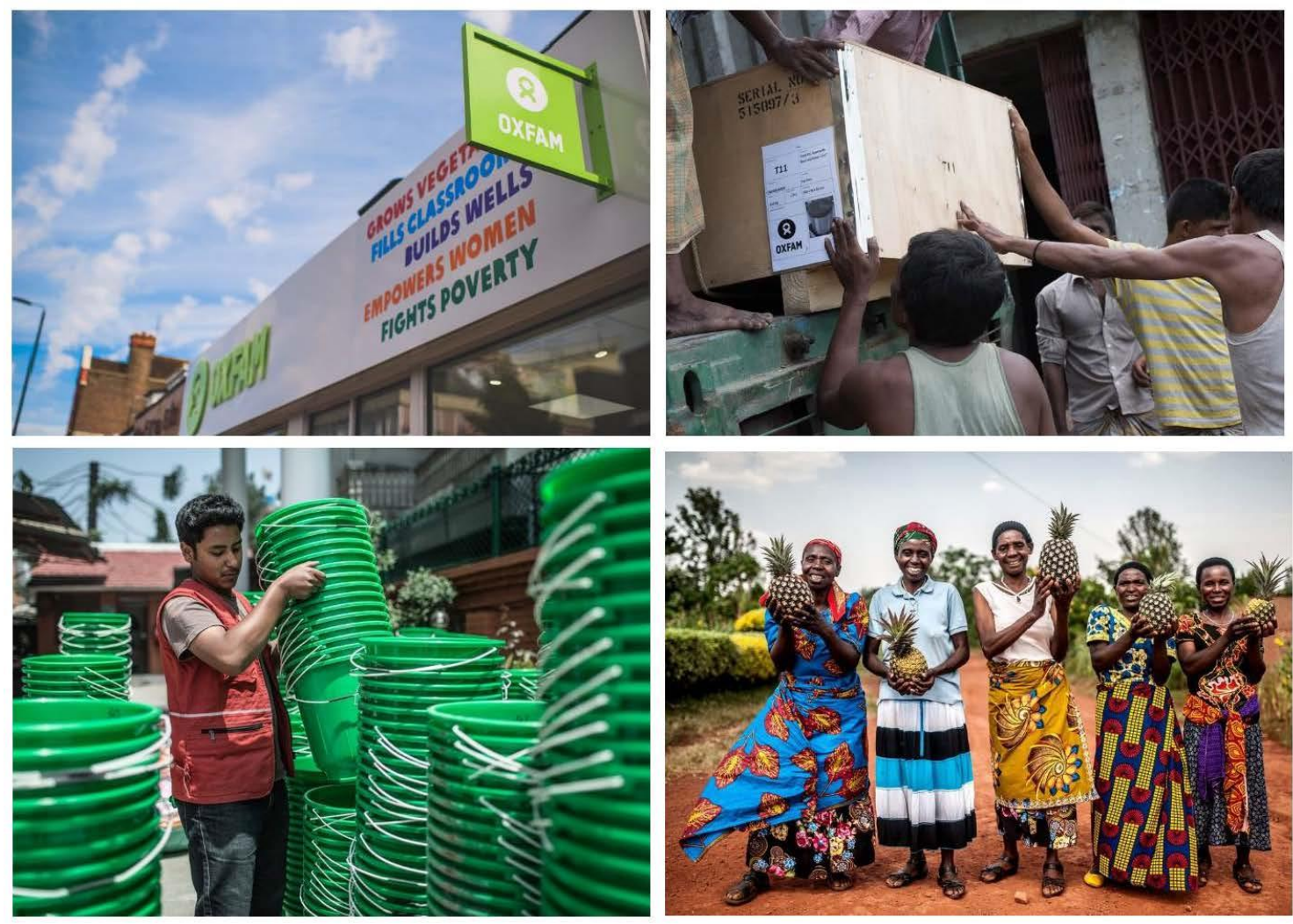

The UK Modern Slavery Act 2015 requires organizations with a turnover of at least $£ 36 \mathrm{~m}$ to make a public statement on steps they are taking to identify and prevent modern slavery in their operations and supply chains. Oxfam GB advocated for this policy development, and this statement relates to steps taken in relation to our own operations and supply chains. Our first statement in $\mathbf{2 0 1 6}$ gave detailed information about our policies and processes to demonstrate transparency on this challenging issue and to encourage other companies to be transparent. This statement is an update on progress against the two-year commitments that we made in that first statement.

SIGNED MARK GOLDRING, CEO, and Caroliine Thomson, Chair of Trustees, Oxfam GB This statement can be downloaded from https://policy-practice.oxfam.org.uk/ 


\section{CONTENTS}

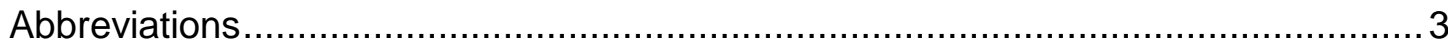

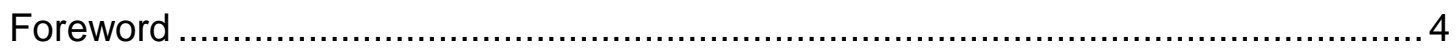

1 Oxfam GB's organizational structure and supply chains .................................. 6

How we work as a confederation: the ‘One Oxfam' model ..................................... 6

Oxfam GB's staff and contingent (contract) workers …..................................... 7

Oxfam International country programme contingent (contract) workers .................... 8

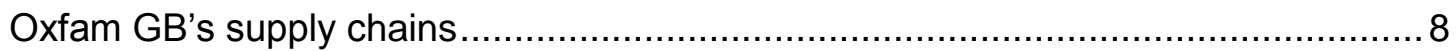

2 Oxfam GB's policies, due diligence processes, risk assessments, action taken and training

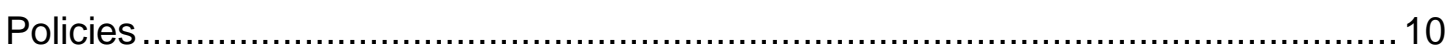

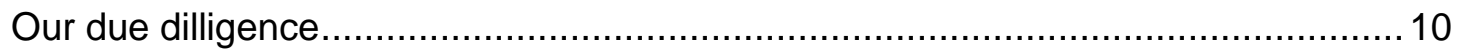

Disclosure of any identified instances of modern slavery and results of any corrective

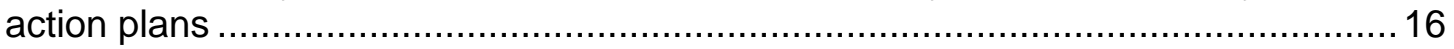

Remedy and compensation provided for labour rights abuses ............................. 16

Company-level grievance mechanisms......................................................... 16

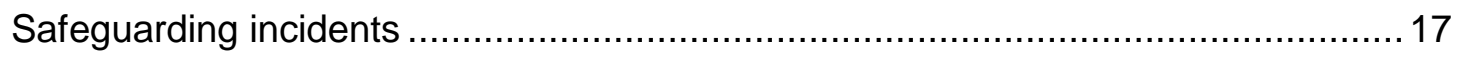

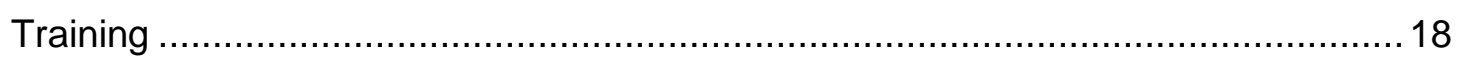

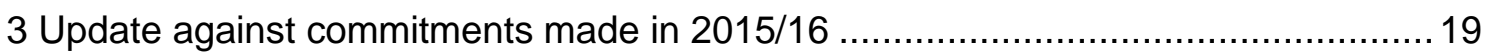

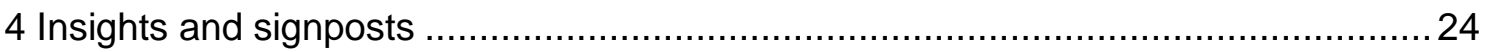

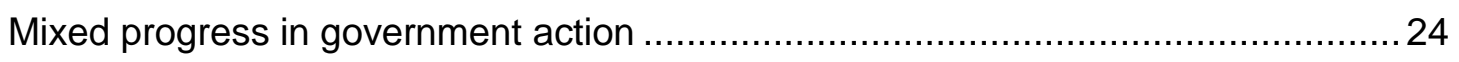

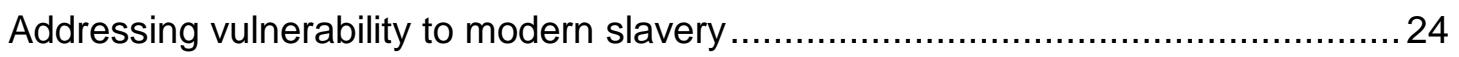

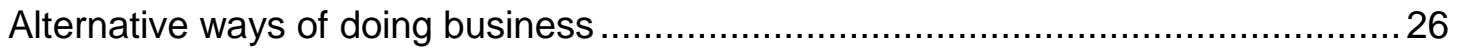

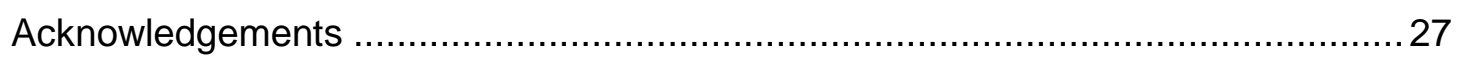

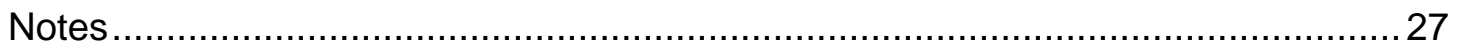




$\begin{array}{ll}\text { ACAS } & \text { Advisory, Conciliation and Arbitration Service } \\ \text { CCS } & \text { Crown Commercial Service } \\ \text { CL1 } & \text { Contingent Labour One } \\ \text { CR } & \text { Corporate responsibility } \\ \text { CRA } & \text { Collective Resource Allocation } \\ \text { ETI } & \text { Ethical Trading Initiative } \\ \text { FOA } & \text { Freedom of association } \\ \text { HFIAS } & \text { Household Food Insecurity Access Scale } \\ \text { HR } & \text { Human resources } \\ \text { IDC } & \text { International Development Committee } \\ \text { ILO } & \text { International Labour Organization } \\ \text { IT } & \text { Information technology } \\ \text { ITUC } & \text { International Trade Union Confederation } \\ \text { KPI } & \text { Key performance indicator } \\ \text { NGO } & \text { Non-government organization } \\ \text { OJTUS } & \text { Oxfam Joint Trade Union Shop } \\ \text { PSEA } & \text { Protection from sexual exploitation and abuse } \\ \text { SDGs } & \text { Wortainable Development Goals } \\ \text { UNGPs } & \text { Workforce Disclosure Initiative } \\ \text { WFTO } & \text { Wair Trade Organization } \\ \text { WDInciples on Business and Human }\end{array}$




\section{FOREWORD}

Modern slavery encompasses horrific human rights abuses, including forced and bonded labour, human trafficking and child labour. Over the past year estimates of people living in modern slavery have grown to 40 million. Of these, $71 \%$ are women and girls, and one in four victims is a child. ${ }^{1}$

Internationally, organizations are on a huge learning curve to understand more about the complexities of addressing modern slavery. Responsible companies are improving their data gathering to get a better view of the hidden risks and vulnerabilities in their operations and supply chains. However, many remain concerned that there is a disincentive to share information and learning and that responsible companies can be undercut by those who inadvertently benefit from modern slavery, or are indeed linked to serious organized crime.

We at Oxfam Great Britain are on our own learning curve. While we have not found any incidents of modern slavery to date, like many other large organizations we recognize that it is pervasive across all sectors and therefore it is likely that slavery exists somewhere in our supply chains and operations. To address this, in 2016 we set out a number of two-year commitments to ensure that we have an effective approach on this issue.

We have progressed well on many of our commitments, including strengthening our governance, raising awareness about the issue and developing a human rights due diligence framework based on good practice guidance from the Ethical Trading Initiative (ETI). ${ }^{2}$ We have included our progress on due diligence in this statement (p.10) in order to share our process and learning. The salient issues ${ }^{3}$ we have identified in the supply chains that we manage from the UK are summarized in Box 1.

\section{Box 1: Salient issues identified in Oxfam GB's UK-managed supply chains}

Supply chains involving direct procurement of manufactured goods (retail, promotional humanitarian, etc.) were identified as having the highest risk of human rights violations in the following countries:

- risk of forced labour in Pakistan, India, Turkey, Poland and Senegal

- risk of child labour in India

- risk of gender discrimination in Pakistan, India and Turkey

- risk to workers' rights to collectively organize in Pakistan, India, China, Indonesia, Turkey, Hong Kong and South Korea

- risk of poverty-line wages in Bangladesh, Malaysia., Mauritius, Rwanda, South Africa, Swaziland and Thailand

Progress on some of our commitments are behind schedule, including writing our modern slavery policy and strategy and developing an assessment framework for in-country operations and supply chains. This is mainly due to our confederation-wide change process (see section 1 for more details) and learning how complex it would be to implement some of the commitments we made in 2016. We have therefore extended the period for some of our commitments from two to three years, allowing us to ensure that the tools and processes we develop will be fit for purpose.

In our 2017 statement, we emphasized the importance of learning from our safeguarding work on sexual abuse and exploitation to inform how we identify, mitigate and respond to modern slavery. We continue to recognize this important overlap, and we will ensure that our approach to modern slavery is informed by learning from the Charity Commission and our Independent Commission ${ }^{4}$ reports, as well as the sector-wide International Development Committee (IDC) report into protection from sexual exploitation and abuse (PSEA) in the aid sector. 
We continue to address the wider issues that drive modern slavery and in June 2018 we launched our Behind the Barcodes campaign. ${ }^{5}$ Oxfam believes that access to decent work on a living wage is one of the fundamental pathways out of poverty and one of the best ways to counter growing inequality. ${ }^{6}$ In the UK, our campaign will both engage the public in campaign activities and undertake insider engagement with supermarkets. We are asking supermarkets to take action to reduce the vulnerability of their workforce to exploitation, such as modern slavery.

We will continue to be open about our own shortcomings and what we are learning, with the intention that this will demonstrate transparency and also encourage it from others. We actively seek to learn from others and welcome feedback from those with expertise that could strengthen our approach.
Oxfam believes that access to decent work on a living wage is one of the fundamental pathways out of poverty and one of the best ways to counter growing inequality.

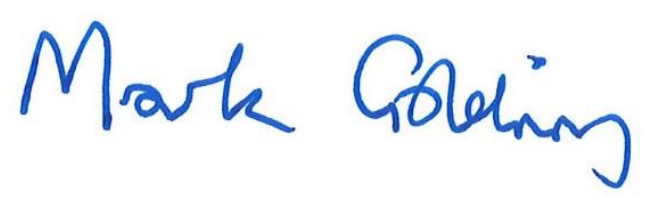

Mark Goldring, CEO, Oxfam GB, September 2018

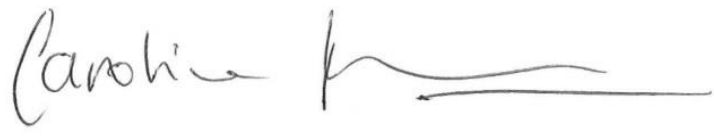

Caroline Thomson, Oxfam GB Chair of Trustees 


\section{OXFAM GB'S ORGANIZATIONAL STRUCTURE AND SUPPLY CHAINS}

In our 2016 statement, we provided a comprehensive overview of Oxfam GB's organizational structure. Oxfam GB's UK-based activities have not changed considerably since then; therefore please see pp.14-22 of Oxfam GB's 2015/16 Modern Slavery Statement for more details.7

However, the way that we work with our country programmes is undergoing a significant change process across the Oxfam confederation. We describe the changes below, as they have affected the timing and increased the complexity of delivering on our commitment to address modern slavery risks in our operations and supply chains that are managed at a country level.

\section{HOW WE WORK AS A CONFEDERATION: THE 'ONE OXFAM' MODEL}

The move towards the 'One Oxfam' or 'Oxfam 2020' model, which began in 2016/17, has required significant organizational changes across the confederation and also within Oxfam GB. The new One Oxfam model is designed to ensure that we:

- are more rooted in the countries where we work;

- are stronger in the way that we influence global, regional and national change to eliminate poverty and injustice;

- are simpler in how we work to reduce cost and complexity and to increase efficiencies;

- are better able to share knowledge, evidence and expertise to deliver high-quality programmes.

As of 2017/18, all Oxfam affiliates contribute a significant proportion of their annual unrestricted programme funds to a confederation-wide pot (the Collective Resource Allocation (CRA)), which funds the core costs of all $68^{8}$ Oxfam country programmes. In addition, all Oxfam affiliates raise restricted funds for country programmes from governmental, corporate and multilateral donors, an arrangement known as the 'Partner Affiliate' function.

Some Oxfam affiliates also provide underpinning systems, policy and processes (such as human resources (HR), information technology (IT), finance and logistics) which enable country offices to operate effectively; this is known as the 'Executing Affiliate' function. Oxfam GB is the Executing Affiliate in 27 countries: Bangladesh, Indonesia, Myanmar, Nepal, Pakistan, the Philippines, Tajikistan, Thailand, the Democratic Republic of Congo (DRC), Ethiopia, Kenya, Rwanda, South Sudan, Tanzania, Iraq, Jordan, Lebanon, Russia, Syria, Yemen, Malawi, Zambia, Zimbabwe, Ghana, Liberia, Mali and Sierra Leone.

These changes have had a significant impact on our ability to progress against our commitment to incorporate our international programmes into the scope of our work. We have prioritized ensuring that our approach is aligned with the new structure, as this will ensure that the systems we develop are fit for purpose and are fully integrated into business-as-usual. For more details, see commitment 1.3 in Table 4.

Our commitment to address modern slavery includes all programmes in countries where Oxfam GB is Executing Affiliate and programmes where we are providing funding as a Partner Affiliate, recognizing that the latter would require collaboration with other Oxfam affiliates and Oxfam International country teams.

For more detailed information on how and where we work and our governance structure, please see our Annual Report and Accounts. ${ }^{9}$ 


\section{OXFAM GB'S STAFF AND CONTINGENT (CONTRACT) WORKERS}

Oxfam GB's headcount of directly employed workers as of 31 March 2017 was 5,274 overall, with 2,230 in the UK and 3,044 overseas. ${ }^{10}$

In our first statement in 2016, we identified agency labour as carrying a higher risk of modern slavery. Therefore, we committed to monitor the number of temporary workers used in our own UK operations and improve the checks we have in place with the agencies that employ them. The number of contingent workers hired in the UK either directly or through our on-site service provider during 2017/18 was 131 .

In the UK, we apply four categories to contingent workers, as outlined in Table 1.

\section{Table 1: Oxfam GB temporary workers in the UK}

\begin{tabular}{|c|c|}
\hline $\begin{array}{l}\text { Category and number of } \\
\text { workers in financial year } \\
2016 / 17\end{array}$ & Current processes \\
\hline $\begin{array}{l}\text { 1. Specialist contractors: } \\
35 \text { workers }\end{array}$ & $\begin{array}{l}\text { Workers are generally contracted on their own terms } \\
\text { (independent contracts, via limited companies or umbrella } \\
\text { company contracts) and are paid according to market rates, } \\
\text { with contracts being flexible for the duration of the } \\
\text { assignment. Minimum day rates are set in line with the } \\
\text { market. } \\
\text { Hired through Crown Commercial Service (CCS)'s } \\
\text { Contingent Labour One (CL1) framework. }\end{array}$ \\
\hline $\begin{array}{l}\text { 2. Agency workers for admin } \\
\text { and clerical roles: } \\
11 \text { workers }\end{array}$ & $\begin{array}{l}\text { We have a rate card for each role agreed in advance with } \\
\text { the agency, which ensures that all temporary workers are } \\
\text { given pay parity from day one. Agency workers are entitled } \\
\text { to holidays from day one on an unpaid basis and we offer } \\
\text { paid leave on a parity basis from day one of an assignment. } \\
\text { Hired through CCS's CL1 framework. }\end{array}$ \\
\hline $\begin{array}{l}\text { 3. Agency workers as drivers, } \\
\text { operations and warehouse } \\
\text { staff: } \\
30 \text { workers }\end{array}$ & \multirow[t]{2}{*}{$\begin{array}{l}\text { Our process for engaging these types of worker is devolved } \\
\text { to commercial teams in the locations using the services. The } \\
\text { teams conduct an annual check with each supplier to } \\
\text { confirm that they comply with the points set out below. }\end{array}$} \\
\hline $\begin{array}{l}\text { 4. Agency workers used by on- } \\
\text { site service providers: } \\
10 \text { workers }\end{array}$ & \\
\hline
\end{tabular}

For all four categories, we can confirm that:

- Oxfam GB agency contracts in the UK do not include any form of accommodation or service package, such as transportation;

- contracts state that overtime is on a voluntary basis only;

- contracts do not allow for fines to be imposed on workers;

- passports are not retained but copied;

- workers are not charged a finder's fee. 
We can also confirm the following for categories 1 and 2 :

- The agencies are required to assure their own position on modern slavery independently, as they exceed the $£ 36 \mathrm{~m}$ annual turnover.

- Information is provided about workers' rights in a language that they understand.

\section{OXFAM INTERNATIONAL COUNTRY PROGRAMME CONTINGENT (CONTRACT) WORKERS}

This year we worked with Oxfam International to survey $67^{11}$ international country programmes and seven regional platforms. We received back 48 survey responses $(65 \%) .{ }^{12,13}$ The questions asked were:

- Do you have any Oxfam workers who are contracted via an employment agency (i.e. their contract is with the agency rather than Oxfam)?

- Do you check that the terms and conditions for the workers provided by the agency are similar to those provided by Oxfam?

Of the 48 surveys received back:

- $75 \%$ (35 respondents) confirmed that they do not have any Oxfam workers who are contracted via an employment agency; ${ }^{14}$

- $27 \%$ (13) confirmed that they do have Oxfam workers who are contracted via an employment agency;

- $92 \%$ (12) of these confirmed that they check that the agency provides similar terms and conditions for its workers to those provided by Oxfam;

- $8 \%$ (one) advised that while they do not check that the agency provides similar terms and conditions for its workers to those provided by Oxfam, they have confirmed that the agency does not retain original passports, charge staff a finder's fee or make any other mandatory deductions (other than legally required ones).

All regions will be receiving basic training on modern slavery over the next year, and we expect that this will improve response rate for next year's survey.

\section{OXFAM GB'S SUPPLY CHAINS}

Our supply chains have not changed significantly from what was reported in our 2015/16 Modern Slavery Statement. All UK-managed supply chains have been mapped in line with the ETI Human Rights Due Diligence Framework, and the tools we use to assess them will be revised to ensure greater understanding of the risk of modern slavery. For more detail on this work, see section 2 of this report. Spending levels have been updated in Table 2. 
Table 2: Oxfam GB's procurement structure and spend 2017/18 (£ million)

\begin{tabular}{|c|c|c|c|c|c|}
\hline $\begin{array}{l}\text { Procurement } \\
\text { category }\end{array}$ & $\begin{array}{l}\text { Managed } \\
\text { from }\end{array}$ & $\begin{array}{l}\text { Value of } \\
\text { spend }\end{array}$ & $\begin{array}{l}\text { Approx. } \\
\text { number } \\
\text { of } \\
\text { suppliers }\end{array}$ & Categories & $\begin{array}{l}\text { Key sourcing } \\
\text { countries }\end{array}$ \\
\hline $\begin{array}{l}\text { 1. Central } \\
\text { Procurement }\end{array}$ & UK & $£ 46 m$ & 2,472 & $\begin{array}{l}\text { Facilities, } \\
\text { logistics, IT, } \\
\text { marketing, } \\
\text { promotional, } \\
\text { fundraising, HR, } \\
\text { finance and } \\
\text { travel }\end{array}$ & UK, China \\
\hline $\begin{array}{l}\text { 2.Sourced by } \\
\text { Oxfam (Retail) }\end{array}$ & UK & $£ 5 m$ & 78 & $\begin{array}{l}\text { Food, everyday } \\
\text { essentials, } \\
\text { cards, } \\
\text { Christmas } \\
\text { ranges. Fifty } \\
\text { percent of our } \\
\text { suppliers are } \\
\text { fair trade }\end{array}$ & UK, India, China \\
\hline $\begin{array}{l}3 . \\
\text { Humanitarian: } \\
31 \\
\text { emergencies } \\
\text { in } 2015 / 16 ; \\
\text { Oxfam GB } \\
\text { reached } 9 \\
\text { million people }\end{array}$ & UK & $£ 4 m$ & 85 & $\begin{array}{l}\text { Water and } \\
\text { sanitation, } \\
\text { health and } \\
\text { hygiene, } \\
\text { shelter, } \\
\text { vehicles, } \\
\text { communications } \\
\text { equipment, held } \\
\text { at the Oxfam } \\
\text { Supply Centre } \\
\text { in Bicester, } \\
\text { Oxfordshire }\end{array}$ & \\
\hline $\begin{array}{l}\text { 4. International } \\
\text { Programmes }\end{array}$ & $\begin{array}{l}51 \\
\text { developing } \\
\text { countries }\end{array}$ & $£ 95 m$ & $\begin{array}{r}2,757 \\
\text { (est.) }{ }^{15}\end{array}$ & $\begin{array}{l}\text { Direct, e.g. } \\
\text { office } \\
\text { equipment, fuel, } \\
\text { chickens. } \\
\text { Indirect, e.g. } \\
\text { utilities, legal } \\
\text { advice. }\end{array}$ & $\begin{array}{l}\text { All the countries } \\
\text { in which Oxfam } \\
\text { GB works }\end{array}$ \\
\hline Global total & & $£ 109.49 \mathrm{~m}$ & & & \\
\hline
\end{tabular}




\section{OXFAM GB'S POLICIES, DUE DILIGENCE PROCESSES, RISK ASSESSMENTS, ACTION TAKEN AND TRAINING}

\section{POLICIES}

Oxfam GB's Corporate Responsibility Policy was scheduled to be updated to reflect our human rights due diligence approach, including modern slavery, in March 2018. However, given the delays to our commitments outlined in the update in section 3 , it was agreed that the Corporate Responsibility Policy would be delayed until December 2018, and that a separate Anti-Slavery Policy would be developed by July 2018. Meanwhile, we continue to work to the policies outlined in our Modern Slavery Statement for 2015/16 (see section 2). ${ }^{16}$

Oxfam's Anti-Slavery Policy was signed off by the Directors and Council in July 2018. It includes a commitment to the proactive prevention of forced labour, including at the recruitment stage, and states our position of zero tolerance to inaction on modern slavery and our commitment to providing or facilitating workers' safety and access to compensation and/or redress (for lost earnings or unpaid wages as well as for pain and suffering ${ }^{17}$ ).

The Corporate Responsibility Policy and strategy are still in development. However, based on the due diligence work we have done so far (outlined below), we can confirm that they will include the following priority commitments. Oxfam GB will:

- work with credible trade unions at local, national and global levels, to understand what action is needed to remove barriers to freedom of association (FOA) and create the enabling conditions for collective bargaining;

- build on the commitments made in Oxfam International's 10-point plan ${ }^{18}$ to strengthen our focus on gender justice and safeguarding in our operations, and apply any learning to our supply chains;

- work with our suppliers to share the names and locations (site level) of first-tier supplier sites, which make up $80 \%$ of our retail spend. This to include detail on whether work is subcontracted, the number of men and women workers and/or small-scale producers involved and whether they have FOA/collective bargaining arrangements; this information to be updated annually. We are committed to being as transparent as possible, while listening to the concerns of our suppliers and respecting the personal data of workers in our supply chains;

- based on our assessment of salient risks, identify where we can work with suppliers to address the risks beyond tier one in our supply chains.

\section{OUR DUE DILLIGENCE}

Oxfam GB is committed to upholding the UN Guiding Principles on Business and Human Rights (UNGPs) and to regularly reporting against them. Therefore, in our 2015/16 Modern Slavery Statement we made a commitment to align our existing due diligence processes with the ETI Human Rights Due Diligence Framework, ${ }^{19}$ which was developed as a practical tool to help businesses execute the UNGPs. The framework outlines key steps that companies and organizations should take to prevent, manage and mitigate human rights abuses in their own operations and in their supply chains. 
As we adapt our tools and processes to reflect this new human rights framework, we continue to follow existing due diligence processes, outlined in the 2015/16 Modern Slavery Statement, pp. $26-43 .^{20}$

\section{Action taken to align with the ETI Human Rights Due Diligence Framework in 2017/18}

\section{Step 1: Mapping our supply chains}

As a starting point, we have used existing data on our supply chains to map the countries and sectors that we buy from. The data available varies depending on the category of spend; however, for retail it includes at a minimum a self-assessment questionnaire for all first-tier sites (final point of manufacture or service) involved in producing our retail products.

Given our low spend, we do not currently assess beyond the first tier of any of our supply chains, apart from where risk is higher or where the final point of manufacture is only a packing site (such sites account for less than $10 \%$ of the supply chain). More detailed information on the data available for each category is given in Table 3 .

Table 3: Oxfam GB's supplier data

\begin{tabular}{|l|l|}
\hline Activity & Data available \\
\hline Retail supply chains: £5m & $\begin{array}{l}\text { Minimum self-assessment questionnaire for all first-tier } \\
\text { manufacturing sites; some more detailed audits are } \\
\text { also available. Fair trade sites have either } \\
\text { accreditation, partners' assessments or more detailed } \\
\text { site-based information. }\end{array}$ \\
\hline $\begin{array}{l}\text { Central Procurement (IT, } \\
\text { facilities, office equipment, } \\
\text { shop fit, promotional items, } \\
\text { on-site services, etc.): £46m }\end{array}$ & $\begin{array}{l}\text { The procurement team has mapped the known } \\
\text { countries and sectors. This includes all first-tier } \\
\text { suppliers where the spend is over £50,000, plus } \\
\text { second-tier site-level data for promotional items, } \\
\text { printed materials and facilities management. With our } \\
\text { IT procurement, we have also indicated known } \\
\text { second-tier sourcing countries, though we do not } \\
\text { collect audit or self-assessment information for site- } \\
\text { level manufacturing activity. }\end{array}$ \\
\hline $\begin{array}{l}\text { Centrally controlled } \\
\text { Humanitarian procurement } \\
\text { (water tanks, tents, toilets, } \\
\text { etc.): £4m }\end{array}$ & $\begin{array}{l}\text { All countries and sectors known; self-assessment } \\
\text { questionnaires required for all suppliers over the } \\
\text { tender threshold (£50k for FY 17/18) }\end{array}$ \\
\hline $\begin{array}{l}\text { In-country procurement } 21 \\
\text { thent }\end{array}$ & Not included in this assessment. \\
\hline
\end{tabular}

The mapping identified that Oxfam GB's supply chains involve 40 countries, across 10 broad sectors (facilities, fleet, freight and couriers, fundraising services, handicrafts, high-skilled professional services, manufacturing, utilities, warehousing and distribution, waste and works contracts) - see Figure 1. 
Figure 1: UK-managed country and sector mapping, based on available data

\begin{tabular}{|c|c|c|c|c|c|c|c|c|c|c|}
\hline Country & 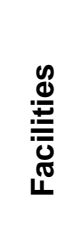 & 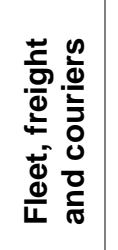 & 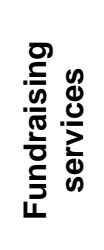 & 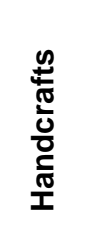 & 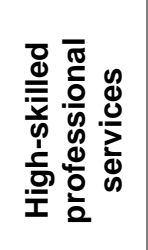 & 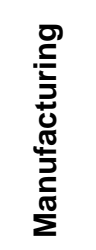 & 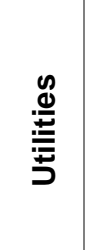 & 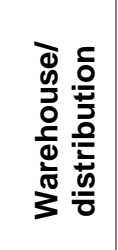 & 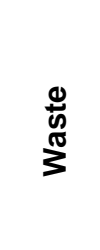 & 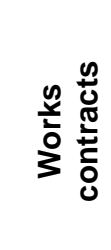 \\
\hline \multicolumn{11}{|l|}{ Austria } \\
\hline \multicolumn{11}{|l|}{ Australia } \\
\hline \multicolumn{11}{|l|}{ Bangladesh } \\
\hline \multicolumn{11}{|l|}{ Belgium } \\
\hline \multicolumn{11}{|l|}{ Bulgaria } \\
\hline \multicolumn{11}{|l|}{ China } \\
\hline \multicolumn{11}{|l|}{ Czech Rep } \\
\hline \multicolumn{11}{|l|}{ France } \\
\hline \multicolumn{11}{|l|}{ Germany } \\
\hline \multicolumn{11}{|l|}{ Guatemala } \\
\hline \multicolumn{11}{|l|}{ Hong Kong } \\
\hline \multicolumn{11}{|l|}{ India } \\
\hline \multicolumn{11}{|l|}{ Indonesia } \\
\hline \multicolumn{11}{|l|}{ Ireland } \\
\hline \multicolumn{11}{|l|}{ Italy } \\
\hline \multicolumn{11}{|l|}{ Japan } \\
\hline \multicolumn{11}{|l|}{ Malaysia } \\
\hline \multicolumn{11}{|l|}{ Mauritius } \\
\hline \multicolumn{11}{|l|}{ Nepal } \\
\hline \multicolumn{11}{|l|}{ Netherlands } \\
\hline \multicolumn{11}{|l|}{ Norway } \\
\hline \multicolumn{11}{|l|}{ Pakistan } \\
\hline \multicolumn{11}{|l|}{ Palestine } \\
\hline Philippines & & & & & & & & & & \\
\hline Poland & & & & & & & & & & \\
\hline Portugal & & & & & & & & & & \\
\hline Rwanda & & & & & & & & & & \\
\hline Senegal & & & & & & & & & & \\
\hline Singapore & & & & & & & & & & \\
\hline South Africa & & & & & & & & & & \\
\hline South Korea & & & & & & & & & & \\
\hline Spain & & & & & & & & & & \\
\hline Swaziland & & & & & & & & & & \\
\hline Sweden & & & & & & & & & & \\
\hline Taiwan & & & & & & & & & & \\
\hline Thailand & & & & & & & & & & \\
\hline Thailand & & & & & & & & & & \\
\hline Turkey & & & & & & & & & & \\
\hline UK & & & & & & & & & & \\
\hline USA & & & & & & & & & & \\
\hline Vietnam & & & & & & & & & & \\
\hline
\end{tabular}




\section{Step 2: Identifying risks relating to workers' rights}

Comprehensive mapping of human rights issues across all countries and sectors in Oxfam GB's supply chains is challenging and resource-intensive. We have written a thorough risk assessment for the UK, which is our most significant sourcing country and one where we have more ability to influence suppliers. However, for all other countries we intend to draw on ETI Norway's ${ }^{22}$ country briefing papers to develop our analysis further, once they are available.

In the meantime, we have drawn on credible and publicly available information to provide visibility of our priority issues (see Figure 2). Informed by the ETI due diligence training and by consultation with our labour rights advocacy team, we have chosen the following indexes and reports to draw on indicators to apply to our own supply chains:

1. International Trade Union Confederation (ITUC)'s Global Rights Index ${ }^{23}$

2. Global Slavery Index ${ }^{24}$

3. World Economic Forum Global Gender Gap Report ${ }^{25}$

4. UNICEF: percentage of children engaged in child labour ${ }^{26}$

5. Wages ratings from Oxfam's Commitment to Reducing Inequality Index. ${ }^{27}$

Figure 2: Snapshot of high-level human rights risk mapping in Oxfam GB's supply chains

\begin{tabular}{|c|c|c|c|c|c|}
\hline Country & 1: ITUC & $\begin{array}{l}\text { 2: Global } \\
\text { Slavery Index }\end{array}$ & 3: WEF & 4: UNICEF & 5: CRI Index \\
\hline Australia & 3 & 52 & 42 & 0 & 37 \\
\hline Austria & 1 & 52 & 80 & 0 & 38 \\
\hline Bangladesh & 5 & 10 & 129 & 4 & 127 \\
\hline Belgium & 2 & 52 & 46 & 0 & 60 \\
\hline Bulgaria & 3 & 32 & 51 & 0 & 94 \\
\hline China & 5 & 40 & 86 & 0 & 52 \\
\hline Czech Republic & 2 & 32 & 92 & 0 & 105 \\
\hline Denmark & 1 & 52 & 36 & 0 & 32 \\
\hline France & 1 & 52 & 64 & 0 & 40 \\
\hline Germany & 1 & 52 & 43 & 0 & 50 \\
\hline Guatemala & 5 & 12 & 101 & 26 & 21 \\
\hline Hong Kong & 5 & 40 & 86 & 0 & \\
\hline India & 5 & 4 & 139 & 12 & 88 \\
\hline Indonesia & 5 & 39 & 108 & 7 & 49 \\
\hline Ireland & 2 & 52 & 50 & 0 & 81 \\
\hline Italy & 1 & 44 & 118 & 0 & 63 \\
\hline Japan & 2 & 41 & 114 & 3 & 59 \\
\hline Malaysia & 4 & 29 & 87 & 0 & 112 \\
\hline Mauritius & 3 & 45 & 113 & 0 & 130 \\
\hline Nepal & 3 & 13 & 110 & 37 & 14 \\
\hline
\end{tabular}




\begin{tabular}{|c|c|c|c|c|c|}
\hline Country & 1: ITUC & $\begin{array}{l}\text { 2: Global } \\
\text { Slavery Index }\end{array}$ & 3: WEF & 4: UNICEF & 5: CRI Index \\
\hline Netherlands & 1 & 50 & 82 & 0 & 48 \\
\hline Pakistan & 5 & 6 & 143 & 0 & \\
\hline Palestine & 5 & 33 & & & \\
\hline Philippines & 5 & 33 & 25 & 11 & 95 \\
\hline Poland & 3 & 24 & 55 & 0 & 68 \\
\hline Portugal & 2 & 49 & 35 & 3 & 75 \\
\hline Rwanda & 2 & 19 & 7 & 29 & 138 \\
\hline Senegal & 4 & 22 & 102 & 23 & 46 \\
\hline Singapore & 3 & 45 & 27 & 0 & \\
\hline South Africa & 2 & 27 & 89 & 0 & 111 \\
\hline South Korea & 5 & 32 & 121 & & 77 \\
\hline Spain & 2 & 52 & 81 & 0 & 98 \\
\hline Swaziland & 5 & 17 & 112 & 7 & 131 \\
\hline Sweden & 1 & 52 & 12 & 0 & 42 \\
\hline Taiwan & 2 & 41 & & & \\
\hline Thailand & 4 & 20 & 24 & 8 & 110 \\
\hline Turkey & 5 & 20 & 128 & 6 & 36 \\
\hline UK & 4 & 52 & 53 & 0 & 33 \\
\hline USA & 4 & 52 & 19 & 0 & 100 \\
\hline Vietnam & 5 & 47 & 33 & 16 & 25 \\
\hline
\end{tabular}

Key: High risk

Low risk

Note: The numbers represent scores in each of the five indexes, and each index has a different system for ranking. For more details, see the individual reports. The blank spaces indicate no information available.

High scores on any of the indicators were then mapped by likelihood of occurrence and severity, taking into account additional information that might affect the risk. For example, the presence of agency workers was considered to increase the likelihood of forced labour, while sites that are accredited by the World Fair Trade Organization (WFTO) were considered to have a lower likelihood of raising concerns on most human rights issues, as its 10 Principles of Fair Trade $^{28}$ aim to address the root causes of human rights abuses. However, we understand that this accreditation does not mitigate all risk, as was evident from our due diligence process, which highlighted the issue of very low wages in some countries where we buy fair trade products. 
Figure 3: Mapping salient human rights issues across the organization

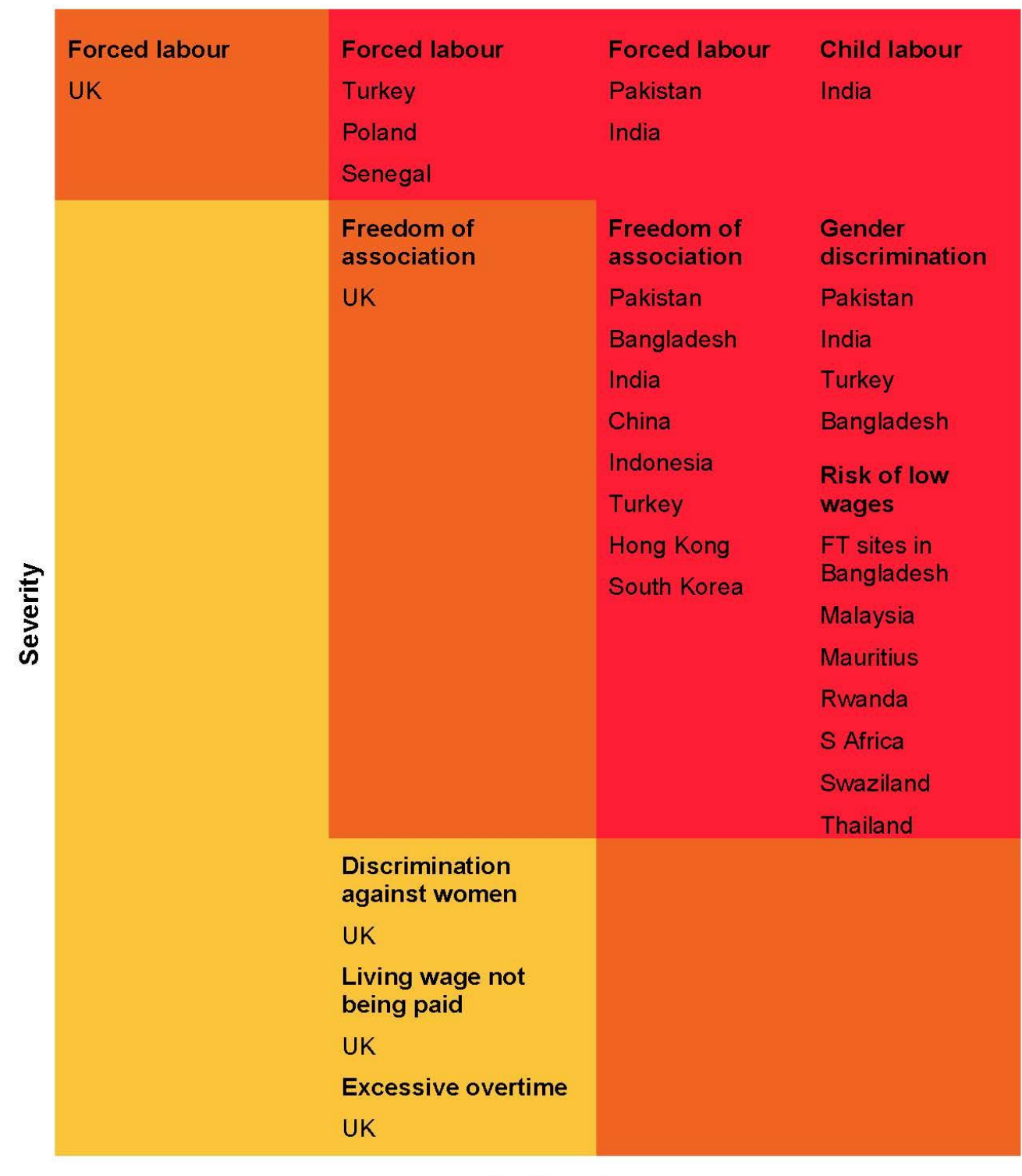

\section{Likelihood}

\section{Salient issues}

Through this process, the following salient issues were identified:

- risk of forced labour in Pakistan, India, Turkey, Poland and Senegal

- risk of child labour in India

- risk of gender discrimination in Pakistan, India and Turkey

- risk to workers' rights to collectively organize In Pakistan, India, China, Indonesia, Turkey, Hong Kong and South Korea

- risk of poverty-line wages in Bangladesh, Malaysia., Mauritius, Rwanda, South Africa, Swaziland and Thailand. 


\section{Next steps}

We are confident that this due diligence assessment covers our supply chains in sufficient breadth. However, the saliency assessment will be mapped against Oxfam's ability to influence its suppliers to decide the priority areas to target for deeper assessment and, where necessary, inform our mitigation plans.

The country and sector analysis will then inform a review of our current tools and frameworks to ensure that they are fit for purpose. International Programme operations will be included in the framework by November 2018 , followed by targeted inclusion of in-country ${ }^{29}$ supply chains.

Our assessment of potential human rights risks will continue to adapt as and when new sources of credible information become available. The November 2018 assessment of our programme countries will also include the US State Department's Trafficking in Persons Report ${ }^{30}$ and the UK government's Human Rights and Democracy Report. ${ }^{31}$

\section{DISCLOSURE OF ANY IDENTIFIED INSTANCES OF MODERN SLAVERY AND RESULTS OF ANY CORRECTIVE ACTION PLANS}

The limitations in our current approach do not yet enable us to say unequivocally that there are no instances of modern slavery occurring in Oxfam's operations or supply chains. What we can say is that the awareness we have built through our investment in training and governance and the work we are putting into developing a better due diligence framework will put us in a stronger position to be confident in our report findings in the coming years.

\section{REMEDY AND COMPENSATION PROVIDED FOR LABOUR RIGHTS ABUSES}

For Oxfam GB staff, the Dealing with Problems at Work policy and guidelines provide a clear process for workers, unions and management to follow to ensure that appropriate investigation, hearings and remedial actions take place.

We do not have a formal mechanism in place for our supply chains, and we are in the process of seeking examples of good practice to inform our approach.

\section{COMPANY-LEVEL GRIEVANCE MECHANISMS}

We have a global grievance procedure for staff and managers, along with a whistle-blowing mechanism and a confidential employee assistance programme. The Oxfam Joint Trade Union Shop (OJTUS) unions are available to support workers through the grievance process along with HR. The grievance guidelines are based on the procedures of the Advisory, Conciliation and Arbitration Service (ACAS) and were reviewed recently in consultation with the unions.

For this financial year, we did not have a mechanism for recording grievances at a global level and therefore we cannot report on the number of grievances raised.

In March 2018, Oxfam GB launched a new third party, independent whistle-blowing hotline and case management system, hosted by NAVEX Global, for use by anyone connected to our work to report concerns related to safeguarding, modern slavery, bullying and harassment and corruption. Anyone using this system can remain anonymous. 


\section{SAFEGUARDING INCIDENTS}

In our 2017 statement we recognized the link between safeguarding and modern slavery. In both cases drivers such as poverty, gender and power make individuals more vulnerable, and similar approaches to prevent, investigate and remediate can be applied.

Grievance mechanisms are often not appropriate for complex cases of abuse, human trafficking or sexual exploitation. Therefore since 2011 Oxfam GB has had a dedicated Safeguarding Team in place, with expert knowledge and skills to address complex cases of abuse and sexual exploitation.

Following criticism earlier this year of how Oxfam had handled historic cases, including sexual misconduct by former employees in Haiti, further important measures have been put in place. The action taken will further strengthen Oxfam's ability to prevent, investigate and address unacceptable behaviour wherever it may occur. We know that we have more to do, not least in ensuring that everyone who works or volunteers for Oxfam or who receives support from the organization feels empowered to challenge unacceptable behaviour.

We are committed to applying a rigorous safeguarding approach to any allegations of abuse, including any instance of modern slavery. We will be working with the Charity Commission, other authorities, our own Independent Commission and across the sector to continue to make improvements.

We remain committed to transparency on allegations of sexual exploitation and abuse perpetrated by any members of our staff or by partners. For the number of incidents reported and investigated by our Safeguarding Team in 2017/18, please see our Annual Report.

\section{OXFAM INTERNATIONAL'S 10-POINT ACTION PLAN}

On 16 February 2018, Oxfam released a 10-Point Action Plan to improve its safeguarding policies and practices. The plan covers three main areas:

1. Inquiry and investigation: a High-Level Commission on Sexual Misconduct, cooperating with authorities on their inquiries.

2. Strengthening safeguarding and organizational culture: greater investment in safeguarding and strengthened policies; creating a zero-tolerance culture; working with the wider sector on new procedures.

3. Recommitment to women's rights: engaging with partners, listening to the public, recommitment to gender justice.

In July 2018 Oxfam announced that it had more than tripled its funding for safeguarding to more than $£ 1.75 \mathrm{~m}$ and that it is training an additional 119 staff to investigate safeguarding incidents around the world.

Beginning in October 2018, Oxfam will report twice-yearly data on all safeguarding cases completed in the previous six months, across all members of its confederation. 


\section{TRAINING}

\section{Operational staff}

Oxfam GB's Safeguarding Team delivers training sessions to staff, partners and volunteers across the organization. The core training can be delivered in half a day, or can take up to three days, (this in-depth training is typically delivered to in-country safeguarding focal points). It includes:

- definitions of safeguarding and the different forms of vulnerability and sexual abuse and exploitation;

- Oxfam's GB's safeguarding policies;

- the reporting process.

In 2017/18 the following teams received face-to-face training:

- all staff in the South Sudan country programme team, who received the half-day training course, with separate sessions for the HR Team and Country Managers;

- UK-based face-to-face fundraisers;

- UK-based Future Skills teams (who work with vulnerable adults in our UK programme work).

The South Sudan country-based focal points received more in-depth training, including how to support the physical and emotional needs of survivors through the reporting process. This was also delivered via Skype to new safeguarding focal points in other countries.

From 2018, we plan to include modern slavery in all safeguarding training.

\section{Procurement teams}

In 2018, Oxfam GB's central (UK) procurement and retail buying teams attended a training session on the ETI Human Rights Due Diligence Framework to help them understand how Oxfam was using this to identify and address all human rights risks, including modern slavery, in its operations and supply chains. The training included:

- an overview of the ETI framework;

- details on what information was included in the country and sector mapping, including sharing the risk indicators and mitigating factors considered;

- a breakdown by team of the salient issues identified, as well as the organizational overview;

- clarification on next steps in working with buyers to map Oxfam's leverage in order to agree priority actions.

We have also adapted the introductory training for all new buyers to include an overview of modern slavery, factors that make workers vulnerable to it and the risks in Oxfam's supply chains. In future years we intend to develop and use a clear framework to assess the impact of our training. 


\section{UPDATE AGAINST COMMITMENTS MADE IN 2015/16}

In 2016, we identified gaps in our approach to identifying and addressing the risk of modern slavery in our operations and supply chains. As a result, we made a number of commitments, to be met over a two-year period. We knew that our commitments were ambitious and at the time we believed them to be achievable. However, while we have made progress against several of these commitments, most significantly creating a new governance model which ensures accountability for all human rights risks across the organization, some have taken longer than initially thought.

Some of these delays, such as the inclusion of our international programmes within the scope of our modern slavery strategy and reporting, were delayed due to large-scale structural changes in the organization (for more information, see section 1: 'How we work as a confederation'). Other commitments, including adopting the ETI approach to due diligence and developing an organization-wide strategy, turned out to be more complex than originally anticipated. We have therefore decided to extend our deadlines by one year to enable the quality of approach that is needed. This will also allow us to incorporate learnings from the Charity Commission and the Independent Commission reviews.

Table 4: Updates against 2016/17 commitments

Commitment 1: Strategy and policy

\begin{tabular}{|c|c|}
\hline Commitment & Update \\
\hline $\begin{array}{l}1.1 \text { Embedded organization- } \\
\text { wide understanding and } \\
\text { responsibility for modern } \\
\text { slavery }\end{array}$ & $\begin{array}{l}\text { Achieved two-year objective and continuing to embed } \\
\text { - Established an organization-wide corporate responsibility } \\
\text { governance model with director-level oversight from all } \\
\text { divisions of the organization. } \\
\text { - Worked with identified senior managers from each division in } \\
\text { the organization to map the specific slavery and human rights } \\
\text { risks in their area and agree the individuals accountable for } \\
\text { taking forward action. }\end{array}$ \\
\hline $\begin{array}{l}\text { 1.2 Develop organization-wide } \\
\text { Modern Slavery Strategy } \\
\text { involving accountable operational } \\
\text { and procurement managers. This } \\
\text { strategy will be directly linked to } \\
\text { our work on wages and freedom } \\
\text { of association. The strategy will } \\
\text { be directly informed by the due } \\
\text { diligence commitments identified } \\
\text { below. }\end{array}$ & $\begin{array}{l}\text { In progress - delayed until November } 2018 \\
\text { - Our Modern Slavery Strategy will form part of our wider human } \\
\text { rights strategy, which will be based on our ongoing due } \\
\text { diligence (see section } 2 \text { for more details). } \\
\text { - Additional resources secured to take forward this work. } \\
\text { - A trade union specialist was contracted for one year to enable } \\
\text { a better understanding of how to integrate freedom of } \\
\text { association into our strategy. }\end{array}$ \\
\hline $\begin{array}{l}1.3 \text { Include International } \\
\text { Programme work in the scope } \\
\text { of our Modern Slavery Strategy } \\
\text { and reporting. By November } \\
2017 \text { we will have defined a } \\
\text { process for assessing risks } \\
\text { related to modern slavery in } \\
\text { Oxfam GB's programmes at } \\
\text { country level. }\end{array}$ & $\begin{array}{l}\text { Delayed to January } 2019 \\
\text { - Significant structural changes for our International Programme } \\
\text { (see section } 1 \text { for more details) have delayed this work. The } \\
\text { changes include operations and supply chains at country level. } \\
\text { - This will include all programmes in countries where Oxfam GB } \\
\text { is Executing Affiliate, and programmes where we are providing } \\
\text { funding as a Partner Affiliate, recognizing that the latter would } \\
\text { require collaboration with other Oxfam affiliates and Oxfam } \\
\text { International country teams. Our approach will be phased, }\end{array}$ \\
\hline
\end{tabular}


starting with a few programme countries. Lessons learned will then inform roll-out.

1.4 Revise current due diligence frameworks informed by the (ETI) model for central, humanitarian and retail procurement teams.

\section{In progress - delayed until March 2019}

- The start of this work was delayed by the need for more resources in the Corporate Responsibility Team.

- Significant progress has been made on this commitment in the last financial year (see section 2 for more details).

- Further work needs to be done to incorporate learning into our assessment tools and response plans.

1.5 Information gathering on good practice policies will take place in 2016/17 to inform the 2017/18 update of our Corporate Responsibility Policy.

\section{Completed, with ongoing review}

- Identified proactive prevention i.e. zero tolerance to inaction on modern slavery as good practice.

- We will continue to seek good practice examples to inform our Corporate Responsibility Policy, which will be updated in November 2019.

Commitment 2: Training and communications to embed understanding of modern slavery

\begin{tabular}{|c|c|}
\hline Commitment & Update \\
\hline $\begin{array}{l}2.1 \text { Organization-wide } \\
\text { communication on the } \\
\text { importance of addressing } \\
\text { modern slavery and what Oxfam } \\
\text { GB's commitments and actions } \\
\text { are. }\end{array}$ & $\begin{array}{l}\text { Completed and ongoing } \\
\text { - CEO's end-of-year letter to staff highlighted our work. } \\
\text { - Summary of the } 2016 / 17 \text { statement was shared with Oxfam's } \\
\text { Trustee and Finance Auditor Group. } \\
\text { - Key points were presented to Oxfam affiliates with trading } \\
\text { activities. } \\
\text { - Shared with all staff through internal bulletins. } \\
\text { - Detailed presentation for interested staff. }\end{array}$ \\
\hline $\begin{array}{l}2.2 \text { Follow-up training for all } \\
\text { procurement teams and } \\
\text { relevant stakeholders on Oxfam } \\
\text { GB's programme to address } \\
\text { modern slavery. }\end{array}$ & $\begin{array}{l}\text { Completed, with ongoing review } \\
\text { - In } 2017 \text { all UK-based procurement teams participated in a four- } \\
\text { hour training session on labour and environmental standards in } \\
\text { our supply chains, with a specific focus on the drivers of } \\
\text { modern slavery. This was delivered by the Corporate } \\
\text { Responsibility team, with input from Oxfam's Ethical Trade } \\
\text { Manager. } \\
\text { - In } 2018 \text { all UK-based procurement teams attended a } \\
\text { presentation delivered by the Corporate Responsibility } \\
\text { Manager on the human rights due diligence process, the } \\
\text { salient risks in Oxfam GB's supply chains and priority next } \\
\text { steps. }\end{array}$ \\
\hline $\begin{array}{l}2.3 \text { Our recruitment training will } \\
\text { include content about modern } \\
\text { slavery }\end{array}$ & $\begin{array}{l}\text { Completed } \\
\text { - In November 2016, a section on modern slavery was added to } \\
\text { the recruitment training course. } \\
\text { - Content was adjusted to reflect our learning in 2017, and more } \\
\text { in-depth training was given to Oxfam GB's recruitment team } \\
\text { (four people) to increase their understanding of the issue and } \\
\text { help them respond to questions when they deliver training. }\end{array}$ \\
\hline $\begin{array}{l}2.4 \text { Identify appropriate ways to } \\
\text { support suppliers }\end{array}$ & $\begin{array}{l}\text { Completed, with ongoing review } \\
\text { - Key retail suppliers were invited to join the training session } \\
\text { mentioned above. } \\
\text { - Targeted follow-up meetings were held with individual } \\
\text { suppliers. } \\
\text { - We will continue to work with and update our suppliers as our } \\
\text { human rights due diligence work continues. }\end{array}$ \\
\hline
\end{tabular}




Commitment
3.1 Develop indicators for
measuring the Procurement
Team's understanding of
modern slavery and the impact
of training

3.2 Seek good practice examples

\section{Update}

Phase 1 complete, with delay to phase 2

- Impact of training completed in 2016/17 was measured and shared in our 2016/17 statement.

- Impact of training was not measured in $2017 / 18$, but this will be assessed when further training is provided on updates to tools and systems based on the human rights due diligence work.

\section{Completed, with continual review}

- The Corporate Responsibility Manager attended the three-day ETI human rights due diligence training.

- She also shadowed the Oxfam Safeguarding Team to learn about our critical incident approach, which has been identified as best practice.

- We will continue to look for examples of best practice and learn from the mistakes and successes of others.

\subsection{Report risk indicators related to modern slavery in our supply chains}

In progress - delayed until March 2019

- This will be completed as part of the human rights due diligence framework.

\section{Commitment 4: Address any risks of modern slavery: actions by department}

\section{Commitment}

4.1 Contingent labour: increase the due diligence process for category 3 agencies to ensure a consistent standard across all three categories

\section{Update}

\section{Completed}

- All checks are now consistent with the government's contingent labour framework (CL1) (see section 1 for more details (UK only). See commitment 4.6 for update on contingent labour in our International Programme).
4.2 On-site contracted services: strengthen our due diligence regarding agency hiring processes for Oxfam House onsite services.

\subsection{Promotional items: develop} appropriate approaches beyond audit with the supplier

\section{Completed}

- Main on-site services supplier has confirmed that no agency labour is used.

- The other supplier has confirmed that checks are in place to ensure that agency workers are not charged recruitment fees and that no passports or identity documents are withheld.

\section{In progress - ongoing}

- Agreement with supplier to work with Community Trade Union to engage its manufacturing sites in the concept of worker dialogue.

- A pilot took place in April 2018 attended by representatives from 13 manufacturers, with sessions led by Community Trade Union and Oxfam. Feedback on the event was positive and we are working together to develop a longer-term programme.

4.4 Retail products: focus on agency hiring practices, with three key sites.

\section{Completed}

- Our buying team met with each supplier to emphasize concerns about contingent labour increasing their vulnerability to modern slavery.

- One supplier owns its site. It is using Stronger Together's 32 resources and training to inform its approach and confirmed that agency workers have the same rights as permanent workers (confirmed by audits). 
- The second supplier also owns its site and has reviewed the policies and processes of its agency labour provider, which is a registered business partner of Stronger Together and uses its tools and materials to inform its due diligence processes.

- The third supplier has become SA8000-certified. ${ }^{33}$ This process includes checks confirming that agency workers are not charged recruitment fees and do not have their documents withheld.

4.5 We will provide training to suppliers that identified forced labour risks in late 2016

\section{Completed, with ongoing review}

- Three suppliers were identified as having sites with contractual clauses requiring overtime from their workers.

- Two of the three suppliers attended a four-hour training session run by Oxfam staff, which included a substantial section on labour rights and modern slavery.

- The third supplier was unable to attend, but was sent a copy of the training materials and engaged in positive discussion.

- Following the session, one supplier has developed an ethical purchasing policy which includes the ETI Base Code ${ }^{34}$.

\subsection{We will work with our International Programme country teams to confirm that we do not use agency staff}

\section{In progress - delayed until March 2019}

\section{Oxfam survey results}

$67^{35}$ international country programmes were asked:
- Do you have any Oxfam workers who are contracted via an employment agency (i.e. their contract is with the agency rather than Oxfam)?

- Do you check that the terms and conditions for the workers provided by the agency are similar to those provided by Oxfam?

Of the 48 surveys received back:

- $\quad 75 \%$ (35 respondents) confirmed that they do not have any Oxfam workers who are contracted via an employment agency. ${ }^{36}$

- $27 \%$ (13) confirmed that they do have Oxfam workers who are contracted via an employment agency

- $92 \%$ (12) confirmed that they check that the agency provides similar terms and conditions for workers to those provided by Oxfam.

- $8 \%$ (one) advised that, while they do not check that the agency provides similar terms and conditions for the workers to those provided by Oxfam, they have confirmed that the agency does not retain original passports or charge staff a finder's fee or any other mandatory deductions (other than legally required ones).

(See section 1: 'Oxfam International country programme contingent (contract) workers' for more detail.)

As the response rate to the survey was not $100 \%$ there are still some gaps in our knowledge. Our aim is to improve the response rate through training of country teams on modern slavery, but will use the information we have gathered so far as a starting point. 
Commitment 5: Monitoring and evaluation reporting and communication

\begin{tabular}{|l} 
Commitment \\
5.1 We will develop key \\
performance indicators to \\
enable us to measure progress \\
against our internal \\
improvement plans and report \\
on progress in our $2016 / 17$ \\
Modern Slavery Statement.
\end{tabular}

5.2 We will develop and report against key performance indicators (KPIs) to the Corporate Responsibility Steering Group on the progress we are making against commitments set out in this statement every six months from December 2016, and we will include a section on modern slavery in Oxfam GB's Annual Report and Accounts.

5.3 Externally, we will continue to undertake advocacy on labour rights in global supply chains, and will ensure that this incorporates our learning and activities relating to modern slavery.

\section{Update}

In progress - delayed to March 2019

- Modern slavery was added to the procurement risk register to ensure that it is visible to the Trustee Audit and Finance Group.

- As part of the process of embedding Oxfam's corporate responsibility governance model, we have mapped the risk in all divisions of the organization, including in our own operations and on-site services as well as in our supply chains. We have highlighted any gaps in process to relevant senior managers.

- The next step will be to agree with senior managers' appropriate steps to address these gaps and reporting mechanisms to track progress.

\section{Completed, with continual review}

- We continue to work with companies as a 'critical friend' to recommend that they integrate their human rights policies into their core business.

- In 2017, we partnered with ShareAction on the Workforce Disclosure Initiative (WDI). ${ }^{37}$

- In 2018 we launched our Behind the Barcodes campaign, which ranks the performance of supermarkets on in-work poverty and egregious labour rights abuses in a range of food commodity sectors. 


\section{INSIGHTS AND SIGNPOSTS}

This section provides an overview of government action on modern slavery, Oxfam's insights, and its advocacy work that calls for action to address the root causes of modern slavery

\section{MIXED PROGRESS IN GOVERNMENT ACTION}

Over the past year, we have continued to see mixed progress on initiatives to tackle modern slavery. The first conviction under the UK's Modern Slavery Act in June 2018 was encouraging; this saw a British citizen convicted for trafficking offences committed overseas. ${ }^{38}$ There is increasing international debate about the need for employers, rather than workers, to pay the cost of any recruitment fees. And we welcome the UK parliament's consideration of improvements to support for survivors and its application of the standards outlined by the Modern Slavery Act to UK government procurement policy and practice. ${ }^{39}$

Oxfam recently supported a collective action calling for the UK government to host a central register of modern slavery statements. ${ }^{40}$ This action was instigated by the UK's first Independent Anti-Slavery Commissioner. The creation of this role in 2014 was a positive development; however, we were sorry to see the first post-holder resign in May 2018. We hope that the learning identified during his tenure will be applied, and that his successor will have the independence required to drive the improvements needed by people living in or at risk of modern slavery. ${ }^{41}$

We have noted developments in the debate on mandatory human rights due diligence, which raises questions about how some companies are engaging with the Sustainable Development Goals (SDGs). More responsible companies are becoming increasingly transparent about the challenges they find in their human rights due diligence and are making public how they plan to address these challenges. Adopting a policy of zero tolerance to inaction is a vital component of human rights due diligence, since a simple approach of zero tolerance to modern slavery can provide an incentive to cover up challenges, to make false claims or to cut and run from a supplier because of reputational risk, without addressing the core problem. An open dialogue between buyer and supplier is more likely to push up quality standards, increase transparency and improve conditions along supply chains.

Other companies are supporting increased regulation, ${ }^{42}$ and this trend is continuing - for example, with the proposals in Hong Kong ${ }^{43}$ and Switzerland. ${ }^{44}$ We commend the Australian government for applying some of the learning from the UK Modern Slavery Act to the Australian Modern Slavery Bill, ${ }^{45}$ but recognize that so much more still needs to be done at national and international levels to adjust the rules of the game so that responsible companies are rewarded by markets when they are transparent about their efforts to do the right thing.

\section{ADDRESSING VULNERABILITY TO MODERN SLAVERY}

Oxfam believes that access to decent work on a living wage provides a fundamental pathway out of poverty, and is one of the best ways to counter growing inequality. ${ }^{46}$ We know that where workers do not earn enough to meet their basic needs, they can be forced to borrow money on terms they may not otherwise have agreed to and may be more vulnerable to exploitation. Recent figures show that half of those affected by forced labour imposed by private actors are being held in debt bondage. ${ }^{47}$ This happens when debt is transformed into a mechanism of control over a person and they are forced to work to pay off that debt (often with unfair or unattainable terms for repayment)..$^{48}$ Oxfam believes that good-quality industrial relations and ensuring workers' access to FOA and collective bargaining is a key route to reducing workers' vulnerability to exploitation, including modern slavery. ${ }^{49}$ 
Over this past year, Oxfam has commissioned research on supermarket supply chains. We found that many of the women and men who produce food products that we eat in the UK are themselves going hungry. For example, in the case of Indian tea and Kenyan green beans, researchers concluded that workers and small-scale farmers earn less than $50 \%$ of what they need for a basic but decent standard of living in their societies. It also found that the situation is much worse for women, with the greatest gap between current incomes and a decent standard of living in sectors where women provide most of the labour. ${ }^{50}$ Across a range of consumer markets, the share of the consumer price that reaches small-scale farmers and workers is typically less than $5 \% .{ }^{51}$

When earnings fall too low, farmers' and workers' access to food is put at risk. To provide a snapshot of this problem, Oxfam conducted Household Food Insecurity Access Scale (HFIAS) surveys in five food sectors. A clear majority of respondents were categorized as either moderately or severely food-insecure, meaning that they or a family member reported having gone without enough food in the previous month.

For example:

- In Italy, $75 \%$ of surveyed women workers on fruit and vegetable farms said that they or a family member had cut back on the number of meals they ate in the previous month because their household could not afford sufficient food.

- In South Africa, over $90 \%$ of surveyed women workers on grape farms reported not having enough to eat in the previous month. Nearly a third said that they or a family member had gone to bed hungry at least once in that time.

- In Thailand, over $90 \%$ of surveyed workers at seafood processing plants reported going without enough food in the previous month. Of those, $54 \%$ of women workers said that there had been no food of any kind to eat at home on several occasions in that time. ${ }^{52}$

The research also showed that such income levels are especially hard to accept when they are compared with the returns at the other end of the supply chain. For example:

- In less than five days, the highest-paid chief executive at a UK supermarket earns the same as a woman picking grapes on a typical farm in South Africa will earn in her entire lifetime.

- Just $10 \%$ of the cash returned to shareholders on average across the three biggest UK supermarkets in 2016 would be enough to lift the incomes of more than 30,000 workers on South African grape farms to a living wage. ${ }^{53}$

We believe that the time is right for a different way of doing business: one that rewards work and not wealth; one which values human and labour rights more than a relentless maximization of returns to shareholders. We know that many thriving businesses already do business in this way. ${ }^{54}$

Our research shows that we can all - governments, companies and citizens alike - do much more to reduce the vulnerability to modern slavery of the women and men working to produce the food we eat. Our Behind the Barcodes campaign recommends actions that companies, governments and citizens can take.

Oxfam's analysis shows that where governments have introduced minimum producer prices (e.g. Ecuadorian bananas, Côte d'Ivoire cocoa, Thai rice), farmers receive around twice the value share of those products than in countries where no such government support is provided. And where governments set adequate minimum wages, workers' earnings come much closer to meeting their costs of living. ${ }^{55}$

We are asking supermarkets to take action, and we outline our recommendations here:

https://indepth.oxfam.org.uk/behind-the-price/ 
For UK supermarket customers, our campaign actions are outlined here:

https://oxfamapps.org/behindthebarcodes/?cid=rdt_barcodes

A major challenge and also an opportunity over the next few years will be to ensure that workers' rights are not undermined by new or renegotiated trade and investment agreements. Recently a French transnational company, Veolia, contested the Egyptian government's introduction of a minimum wage, on the basis that it reduced its predicted profits. ${ }^{56}$ The case was eventually concluded in Egypt's favour, ${ }^{57}$ but the cost and length of these legal proceedings diverted significant financial and human resources that could have been more productively spent. This case is just one indication of the extent to which the rudiments of new agreements will need to be changed if they are to contribute to workers' well-being.

\section{ALTERNATIVE WAYS OF DOING BUSINESS}

Civil society organizations (CSOs) have often been at the forefront of developing alternative ways of doing business that reduce the vulnerability of workers and producers. For example, Oxfam has supported cooperatives and equitable businesses such as Amul, Cafédirect and Just Change.

Through our advocacy work, we continue to work with businesses to challenge exploitative models and develop practical commercial alternatives for doing business in ways which share prosperity with a wider group of stakeholders than shareholders alone, and in 2017 we set up our Future of Business Initiative. ${ }^{58}$ To explore how companies can transform their procurement approach, we have also initiated the Fair Value Club. ${ }^{59}$ This is a platform for brands and retailers who are serious about promoting alternatives in their supply chains.

Throughout our statement, we have talked about how vulnerability to all forms of modern slavery is driven by an imbalance of power. Business structures that seek to balance the interests of different stakeholder groups offer an alternative to shareholder-based models and we believe these alternative models can significantly improve the livelihoods of the world's most marginalized women and men. 


\section{ACKNOWLEDGEMENTS}

This statement was written by Sophie Brill, Corporate Responsibility Manager; Alex ColeHamilton, Head of Corporate Responsibility; and Beck Wallace, Ethical Trade Advisor, Oxfam GB. We acknowledge the invaluable comments provided by Klara Skrivankova, Anti-Slavery International. We would also like to thank Oxfam GB staff members Anna Coryndon, Nikki Glover, Caroline Gow, Sian Thomas, Sara Barakat, Jim Thompson, Phil Perkins, Jane Randrup, Rachel Wilshaw, Sian Ley, Sophie Bowell and Tricia O'Rourke.

Front cover photos, clockwise from top left:

The Oxfam shop in Cowley Road, Oxford. Photo: Rachel Manns/Oxfam

Emergency aid being unloaded in Cox's Bazar, Bangladesh. The shipment was sent from Oxfam's emergency warehouse in the UK and contained water and sanitation equipment for the camps set up for Rohingya refugees. Photo: Bekkii Frost/Oxfam

Members of the Tuzamurane Cooperative, which grows and sells pineapples in Eastern Rwanda. The women's cooperative was set up 10 years ago with the aim of improving horticultural skills and access to markets and savings schemes. Photo: Aurelie Marrier d'Unienville/Oxfam

Oxfam buckets for distribution in Tundikhel camp for internally displaced people in Nepal, 2015. Buckets are vital for collecting water for drinking and washing in emergencies. Photo: Pablo Tosco/Oxfam

\section{NOTES}

1 International Labour Organization (ILO) and Walk Free Foundation in partnership with the International Organization for Migration (IOM) (2017). Alliance 8.7 Global Estimates of Modern Slavery: Forced labour and forced marriage. http://www.ilo.org/wcmsp5/groups/public/---dgreports/---dcomm/documents/publication/wcms_575479.pdf

2 Ethical Trading Initiative (ETI) (2016). Human rights due diligence framework. https://www.ethicaltrade.org/resources/human-rights-due-diligence-framework

3 Defined by the UN Guiding Principles on Business and Human Rights as 'The human rights at risk of the most severe negative impact through the company's activities and business relationships.' Available at: https://www.ungpreporting.org/resources/salient-human-rights-issues/

4 The Independent Commission is a group of international experts from business, government and civil society, looking at systemic change within Oxfam and the wider humanitarian and development sector. See: https://independentcommission.org/

5 Behind the Barcodes campaign action can be found here: https://oxfamapps.org/behindthebarcodes/

6 R. Wilshaw, S. Hamilton, J. Théroux-Séguin and D. Gardener (2015). In Work But Trapped in Poverty: A summary of five studies conducted by Oxfam, with updates on progress along the road to a living wage. https://policypractice.oxfam.org.uk/publications/in-work-but-trapped-in-poverty-a-summary-of-five-studies-conducted-by-oxfamwit-578815

7 Oxfam GB (2016). Oxfam GB Statement on Modern Slavery: For the financial year 2015/16. https://policypractice.oxfam.org.uk/publications/oxfam-gb-statement-on-modern-slavery-for-the-financial-year-201516-620092

8 This figure includes Russia, which is excluded from Oxfam International's Country (Annual) Operational Report mentioned on $\mathrm{p} 8$ as it is an advocacy rather than programme office, and the survey is focused on programmes. Russia will be included in our human rights due diligence and we will follow up with the country office separately as needed.

9 Oxfam (2017). Oxfam Annual Report \& Accounts 2016/17. http://www.oxfam.org.uk/what-we-do/about-us/plansreports-and-policies/annual-report-and-accounts

10 In previous statements, we reported headcount figures as of 1 April. We have changed to reporting from 31 March to align with our annual report and accounts.

11 See note 7.

12 The total excludes two countries (Mauritania and Niger) which used the old survey or did not answer the agency hiring questions. It includes three surveys from country regions (Asia, Latin America and the Caribbean, Southern Africa). 
13 The questions were included in Oxfam International's Country (Annual) Operational Report. This incorporates up to five different templates, and the modern slavery questions were in the Global Legality Annex. As these are new questions, they were highlighted in the guidance documents that were sent to country teams. However, this annex is usually updated only if the information has changed from the previous year, which could explain why there was not a $100 \%$ response rate

14 This included three who answered no to Q1 but yes to Q2 (Jordan, Nigeria and Pakistan).

15 The increase in these numbers from those reported in our 2017 statement represents an increased number of countries using a centralized system for recording procurement spend.

16 Oxfam (2016). Oxfam GB Statement on Modern Slavery: For the financial year 2015/16, op. cit.

17 ETI (2017). Base Code Guidance: Modern slavery. https://www.ethicaltrade.org/resources/base-code-guidancemodern-slavery

18 Oxfam (2018). Stamping out abuse: Information and updates. https://www.oxfam.org.uk/what-we-do/aboutus/stamping-out-abuse

19 ETI (2016). Human rights due diligence framework, op. cit.

20 Oxfam (2016). Oxfam GB Statement on Modern Slavery: For the financial year 2015/16, op. cit.

21 Sourced by Oxfam's country offices rather than through our head office procurement team

22 Ethical Trading Initiative Norway, website: http://etiskhandel.no/English

23 ITUC (2018). ITUC Global Rights Index 2018. https://www.ituc-csi.org/ituc-global-rights-index-2018

24 The Global Slavery Index (2018). Modern slavery: A hidden, everyday problem. https://www.globalslaveryindex.org/

25 World Economic Forum (WEF) (2017). The Global Gender Gap Report 2017. https://www.weforum.org/reports/theglobal-gender-gap-report-2017

26 UNICEF (2017). Child labour. https://data.unicef.org/topic/child-protection/child-labour/

27 M. Lawson and M. Martin (2017). The Commitment to Reducing Inequality Index: A new global ranking of governments based on what they are doing to tackle the gap between rich and poor. Development Finance International and Oxfam. https://policy-practice.oxfam.org.uk/publications/the-commitment-to-reducing-inequalityindex-a-new-global-ranking-of-governments-620316

28 World Fair Trade Organization (WFTO). 10 Principles of Fair Trade. https://wfto.com/fair-trade/10-principles-fairtrade

29 See note 19

30 U.S. Department of State (2018). 2018 Trafficking in Persons Report. https://www.state.gov/j/tip/rls/tiprpt/

31 Foreign and Commonwealth Office (2017). Human Rights and Democracy Report 2017 https://www.gov.uk/government/publications/human-rights-and-democracy-report-2017

32 Stronger Together is a business-led initiative aiming to reduce modern slavery. It provides guidance, training, resources and a network to work together to reduce exploitation. See: https://www.stronger2gether.org/

33 The SA8000® Standard is the leading social certification standard for factories and organizations across the globe. See: http://www.sa-intl.org/index.cfm?fuseaction=Page.ViewPage\&PagelD=1689

34 Ethical Trading Initiative. ETI Base Code. Available at: https://www.ethicaltrade.org/eti-base-code

35 See note 7

36 This included three which answered no to Q1 but yes to Q2 (Jordan, Nigeria and Pakistan).

37 See: https://shareaction.org/wdi/

38 The Telegraph (2018). Nurse who used voodoo to traffic women is first person convicted under modern slavery laws. https://www.telegraph.co.uk/news/2018/06/28/voodoo-nurse-becomes-first-person-convicted-modern-slaverylaws/

39 Independent Anti-Slavery Commissioner (2018). Government must use the power of public procurement to tackle slavery. https://www.antislaverycommissioner.co.uk/news-insights/government-must-use-the-power-of-publicprocurement-to-tackle-slavery/

40 Independent Anti-Slavery Commissioner (2018). Joint Statement Calls on Government for Central Modern Slavery Registry. https://www.antislaverycommissioner.co.uk/news-insights/joint-statement-calls-on-government-for-centralmodern-slavery-registry/

41 Independent Anti-Slavery Commissioner (2018). Ending my tenure as Independent Anti-Slavery Commissioner http://www.antislaverycommissioner.co.uk/news-insights/ending-my-tenure-as-independent-anti-slaverycommissioner/

42 Independent Anti-Slavery Commissioner (2018). Joint Statement Calls on Government for Central Modern Slavery Registry, op. cit.

43 Lexology (2018). Modern slavery - the compliance risk for corporates in Hong Kong and beyond. https://www.lexology.com/library/detail.aspx?g=8b3da899-f523-4ece-b7c1-36a1bc03edcc

44 Herbert Smith Freehills (2017). Swiss Parliament calls for parent company liability for human rights breaches https://www.herbertsmithfreehills.com/latest-thinking/swiss-parliament-calls-for-parent-company-liability-for-humanrights-breaches 
45 Parliament of Australia (2018). Modern Slavery Bill 2018.

https://www.aph.gov.au/Parliamentary_Business/Bills_Legislation/Bills_Search_Results/Result?bld=r6148

46 R. Wilshaw et al. (2015). In Work But Trapped in Poverty, op. cit.

47 ILO and Walk Free Foundation in partnerships with the IOM (2017). Alliance 8.7 Global Estimates of Modern Slavery, op. cit.

48 ILO (2014). Prevention and Elimination of Bonded Labour: The potential and limits of microfinance-led initiatives, p2, 1.1. http://www.ilo.org/wcmsp5/groups/public/---ed_norm/---declaration/documents/publication/wcms_334875.pdf

49 ETI. Modern slavery. https://www.ethicaltrade.org/issues/modern-slavery

50 R. Willoughby and T. Gore. (2018). Ripe for Change: Ending human suffering in supermarket supply chains. Nairobi: Oxfam. Retrieved from: http://policy-practice.oxfam.org.uk/publications/ripe-for-change-ending-humansuffering-in-supermarket-supply-chains-620418 This is the UK report of Oxfam's Behind the Barcodes food supply chain campaign. The whole set of campaign publications is available here: https://indepth.oxfam.org.uk/behind-theprice/; and the campaign action is available here: https://oxfamapps.org/behindthebarcodes/?cid=rdt_barcodes

51 R. Wilshaw (2018). UK Supermarket Supply Chains: Ending the human suffering behind our food. Oxfam GB. p.6. https://policy-practice.oxfam.org.uk/publications/uk-supermarket-supply-chains-ending-the-human-suffering-behindour-food-620428

52 Ibid., p.5.

53 lbid.

54 S. Jennings, E. Sahan and A. Maitland (2018). Fair Value: Case studies of business structures for a more equitable distribution of value in food supply chains. Oxfam. https://policy-practice.oxfam.org.uk/publications/fair-value-casestudies-of-business-structures-for-a-more-equitable-distributio-620452

55 R. Wilshaw (2018). UK Supermarket Supply Chains: Ending the human suffering behind our food, op. cit., pp.14-15.

56 UNCTAD Investment Policy Hub. 2012 Veolia v. Egypt. http://investmentpolicyhub.unctad.org/ISDS/Details/458

57 International Centre for Settlement of Investment Disputes (ICSID) (2018). Veolia Propreté v. Arab Republic of Egypt. https://icsid.worldbank.org/en/Pages/cases/casedetail.aspx?CaseNo=ARB/12/15

58 See this blog by Alex Maitland (2018) which explains the background to this initiative: A fairer way to do business? https://views-voices.oxfam.org.uk/private-sector/2018/05/a-fairer-way-to-do-business

59 S. Jennings, E. Sahan and A. Maitland (2018). Fair Value: Case studies of business structures for a more equitable distribution of value in food supply chains. Op. cit. 



\section{UNWILLING LABOUR: EVERYDAY DISEMPOWERMENT CAN INCREASE THE VULNERABILITY OF WOMEN LIKE BUDI TO MODERN SLAVERY}

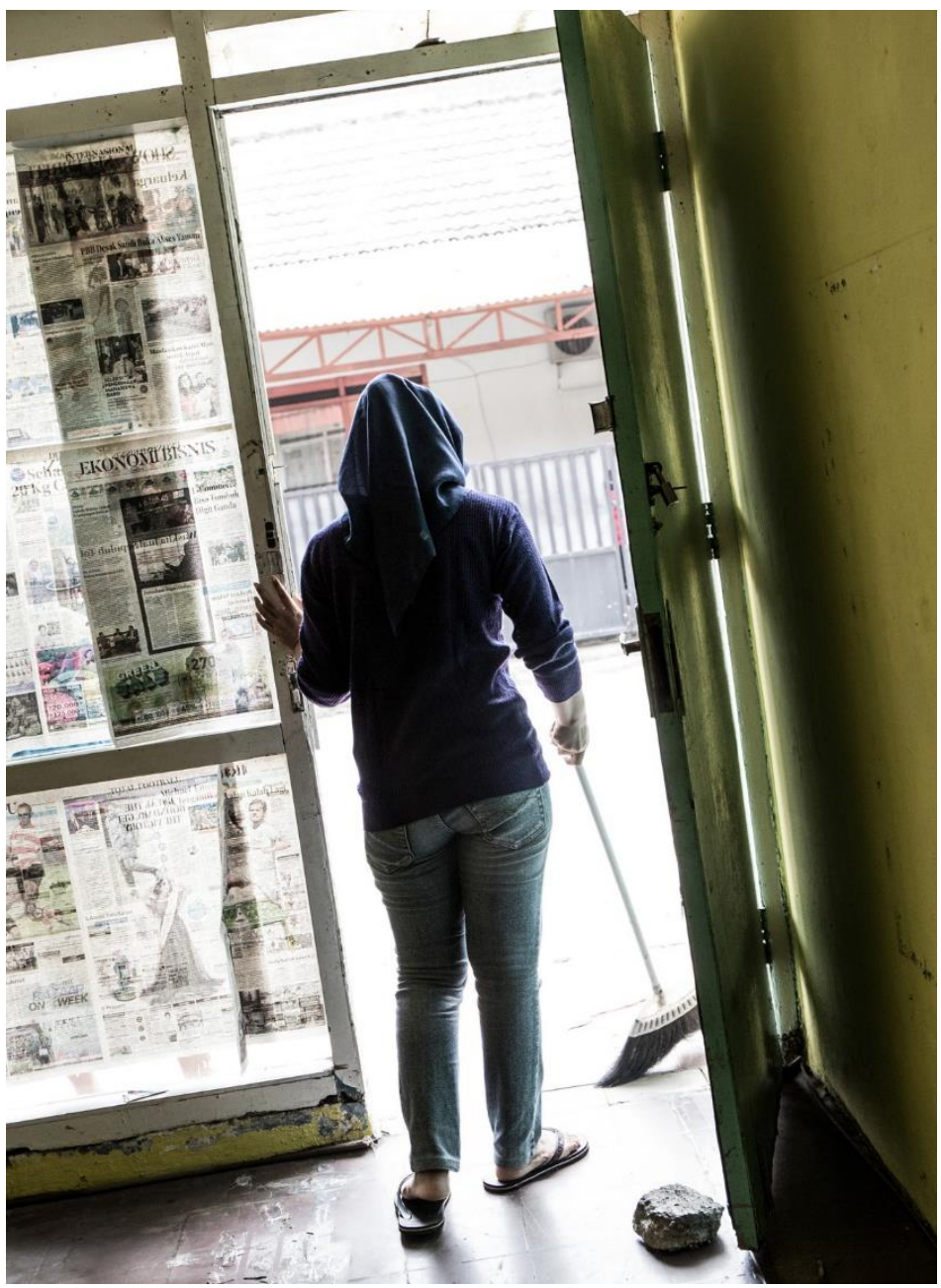

Photo: Adrian Mulya, Sustainable Seafood Alliance Indonesia

Budi, aged 28, was until recently a worker in Indonesia's shrimp industry. To earn the minimum wage, she reported that she often skipped lunch and toilet breaks and worked an hour of unpaid overtime every day to try and meet her target for peeling shrimps. The seafood industry is worth more than $\$ 150$ bn per year globally. But it comes at an unacceptable price: the suffering of the people who work in it.

Oxfam's Behind the Barcodes campaign highlights that millions of farmers and workers who produce the food we all eat are forced to work long hours in inhumane conditions.

Women seafood workers are overwhelmingly concentrated in the worst conditions, with very little job security., Several women told campaign researchers that, to get a job, they must have a pregnancy test, at their own expense; if found to be pregnant while working, they would lose their job. Often, they get no maternity leave, so they have to return to work soon after giving birth. Sometimes they are not able to change sanitary towels during their shifts. They don't always have the protective equipment to deal with very cold work environments or to handle dangerous chemicals such as chlorine. Active participation of women workers in trade unions was also found to be low. For more information, see Supermarket Responsibilities for Supply Chain Workers' Rights. 
This is the everyday reality for millions of women forced to work in ways they have no choice over. They feel unable to speak up for fear of losing their jobs. Workers living in these circumstances who experience this level of disempowerment are more vulnerable to modern slavery than those in decent work.

It doesn't have to be this way. BASIC's research for Oxfam shows that where governments set the minimum wage at an adequate level, workers' earnings come much closer to the living wage benchmark, and when workers can organize they have more power in the face of exploitative practices.

We call on everyone reading this statement to take action to reduce the vulnerability to modern slavery of the women and men who produce our food. Please follow these links to find out how:

Campaign publications: https://indepth.oxfam.org.uk/behind-the-price/

UK supermarket customers can find our campaign action here:

https://oxfamapps.org/behindthebarcodes/?cid=rdt_barcodes

\section{(C) Oxfam GB September 2018}

This publication is copyright but the text may be used free of charge for the purposes of advocacy, campaigning, education, and research, provided that the source is acknowledged in full. The copyright holder requests that all such use be registered with them for impact assessment purposes. For copying in any other circumstances, or for re-use in other publications, or for translation or adaptation, permission must be secured and a fee may be charged. Email policyandpractice@oxfam.org.uk

The information in this publication is correct at the time of going to press.

Published by Oxfam GB under ISBN 978-1-78748-335-4 in September 2017. DOI: 10.21201/2018.3354

Oxfam GB, Oxfam House, John Smith Drive, Cowley, Oxford, OX4 2JY, UK.

Oxfam GB is a member of Oxfam International. 